\title{
EFFECT OF GIRDLING AND GIBBERELLIC ACID APPLICATION ON YIELD AND FRUITS QUALITY CHARACTERISTICS OF BALADY MANDARIN
}

\author{
Misa El sayed \\ Department of Plant production, Desert Research Center, Cairo, Egypt \\ E-mail: misaelsayed@yahoo.com
}

\begin{abstract}
$\mathrm{T}$
he present study was carried out during two successive of 2016 and 2017 on 10 years old Balady mandarin (Citrus reticulate Blanco) trees budded on sour orange rootstock (Citrus aurantium L. Osbeck) and spaced $3.5 \times 3.5$ meters apart. Trees have been treated with girdling and gibberellic acid and were grown in sandy soil under drip irrigation system in a private orchard at Alkamal region- Ismalia Governorate, Egypt, in July and December. The aim of this work was to study the effect of girdling and gibberellic acid on the vegetative growth, yield and fruit quality. The chosen trees girdled with $2 \mathrm{~mm}, 4 \mathrm{~mm}$ width and gibberellic acid was sprayed (at 50 and $100 \mathrm{ppm}$ ) alone or in combination with girdling in each season. Results showed that, girdling $4 \mathrm{~mm}+100 \mathrm{ppm}$ gibberellic acid have given the best enhanced vegetative growth parameters in terms of leaf area, carbohydrate and chlorophyll contents in the leaves of Balady mandarin trees in both seasons. Moreover, treatment of girdling $4 \mathrm{~mm}$ in December and girdling $4 \mathrm{~mm}+50 \mathrm{ppm} \mathrm{GA}_{3}$ gave the best fruit length, diameter as compared to control treatment. Yield and fruit quality of the chosen trees were significantly increased by all treatments as compared to control in both seasons.
\end{abstract}

Keywords: girdling, gibberellic acid, Balady mandarin, fruit quality

\section{INTRODUCTION}

In Egypt, citrus is a backbone of fruit crop cultivation. However, Balady mandarin fruits occupy the third rank after Navel orange and Valencia orange fruits. Mandarin (Citrus reticulate Blanco) is a promising export fruit crop in Egypt. Citrus trees representing the most important fruit crop in Egypt, occupy around 395730 feddans producing about 3730685 ton fruits. Mandarin trees occupy 101342 feddans and produce around 885365 tons, as reported by the annual statistics of Ministry of Agriculture in 2015.

Balady Mandarin (Citrus reticulata Blanco), is one of the popular citrus cultivars due to the beautiful shape, easy to peel, and rich in vitamin-C 
with fair amounts of vitamins $\mathrm{A}$ and $\mathrm{B}$ and other antioxidant compounds. Besides, they are rich sources of minerals (calcium, phosphorus and iron). The juice is very refreshing, delicious and soothing (Ahmed et al., 2007).

Different types of girdling particularly for branches and limbs can increase the number of flowers, set fruitlets, fruit yield as well as leaf photosynthetic pigments, endogenous hormones content and retained fruit/ branch of Washington Navel orange (Citrus sinensis L. Osbeck) trees. In addition, an intensified fertilization program must be accompanied to promote leaf / fruit ratio and the fruit physical and chemical properties as reported by Ibrahim et al. (2016). On the other hand, Rivas et al. (2007) reported that girdling trunk few weeks before flowering of mandarin trees, failed to induce any differences in the total chlorophyll concentration between control and girdled trees. Girdling effect has been related to the accumulation of photo assimilates in the canopy as a result of the interruption of the downward transport of soluble sugars, resulting in increasing in fruit set in citrus. Girdling applications are important and have been used worldwide for centuries in citrus and other fruit tree crops. Girdling treatment led to an increase in the fruit yield, fruit set and fruit size of the Robinson mandarin (Mostafa and Saleh, 2006 and Yilmaz et al., 2018).

Girdling consists of the removal of a strip of bark from the trunk or major limbs of a fruit tree, which blocks the downward translocation of photosynthates and metabolites through the phloem, thus reducing fruit drop and enhancing fruit growth and yield (Mostafa and Saleh, 2006; Raveh, 2013 and Zhao et al., 2013).

Girdling applications at different times are used to increase the yield of some citrus varieties, such as Robinson, Nova, Dancy, Osceola, Klemantin, Minneola, Orlando and Ortanique, which are self-sterile. The fruit set process is complex because photosynthetic activity and thus, the production of photosynthetic compounds, can be altered by sink demand. Girdling effect is related to the accumulation of photoassimilates in the canopy as a result of the interruption of the downward transport of soluble sugars resulting in the increase in fruit set in citrus (Rivas et al., 2007). In addition, girdling treatments increased yield by $125 \%$ in mandarins (Rivas et al., 2006). Mahouachi et al. (2012) found that girdling increases gibberellic acid concentration when performed on branches of Satsuma mandarin at anthesis. Also, many times girdling and gibberellic acid sprays are used together shortly after anthesis as they have a synergistic effect on increasing berry size (Brar et al., 2008).

Plant growth regulators as foliar applications are the most powerful tools used for manipulating tree growth, flowering, yield and fruit quality traits (Ashraf et al., 2013). The use of girdling and gibberellic acid $\left(\mathrm{GA}_{3}\right)$ has become a wide spread practice in the citrus producing countries of the world to improve fruit quality Moreover, $\mathrm{GA}_{3}$ has increased the yield of fruit in Balady mandarin (El-Sese, 2005). Preharvest application of growth regulators 
like $\mathrm{GA}_{3}$ along with mechanical treatments like girdling reduced weight loss $(\%)$, decay (\%), shattering (\%), total spoilage (\%) and acidity (\%) while it increased berry colour, TSS and TSS/acid ratio compared to control after 45 days of storage at $0^{\circ} \mathrm{C}, \mathrm{RH}$ 90-95\% (Abd El-Rahman, 2007 and Saini et al., 2011). GA 3 applied to clusters and or trunk girdling increased berry weight and vine yields significantly over the control (Harrell and Williams, 1987). Girdling and $\mathrm{GA}_{3}$ sprays are used together shortly after anthesis as they have a synergistic effect on increasing berry size (Brar et al., 2008 and Harrell and Williams, 1987). Girdling in combination with an application of $\mathrm{GA}_{3}$ indicates that $\mathrm{GA}_{3}$ may possibly mitigate the depressing effect of girdling on stomatal conductance, and subsequently whole vine water use (Williams and Ayars, 2005). In addition, preharvest $\mathrm{GA}_{3}$ applications were found to be improved growth parameters of Washington Navel orange trees (Hanafy et al., 2012). An important and distinctive link in the technology of growing table grapes is the application of growth regulators or girdling (Crupi et al., 2016). Mandarin fruit set may also be improved by cultural practices like branch girdling, either alone or in combination with other practices.

One of the practices that can be used to increase production and fruit set is the girdling, whose function is to promote accumulation of carbohydrates in the aerial parts of plants (Rivas et al., 2006). Thus, the objective of this study was to evaluate the effects of girdling and application of $\mathrm{GA}_{3}$ on yield and fruits quality characteristics of Balady mandarin trees.

\section{MATERIALS AND METHODS}

\section{Plant Material and Site Experience}

The present study was carried out during 2016 and 2017 seasons on 10 years old Balady mandarin (Citrus reticulate Blanco) trees budded on sour orange rootstock (Citrus aurantium L. Osbeck) and spaced $3.5 \times 3.5$ meters apart. Trees were grown in sandy soil under drip irrigation system in private orchard at Al-kamal region, Ismalia Governorate, Egypt.

This study was carried out to explore possibilities of inducing fruitfulness through the use of girdling operations and $\mathrm{GA}_{3}$. Girdling was carried out before blossoming (late December) and on July with about $2 \mathrm{~mm}$ and $4 \mathrm{~mm}$ width around trunk using a knife without injuring the wood layers. Gibberellic acid was sprayed at 50 and100 ppm twice in July and December.

\section{Experiment Design and the Treatments}

Factorial design - Time of treatment was the main factor and the sub main factor was the following treatments:

1- Control (untreated)

2- Girdling (2 mm)

3- Girdling $(4 \mathrm{~mm})$

4- 50 ppm $\mathrm{GA}_{3}$ 
5- $100 \mathrm{ppm} \mathrm{GA} 3$

6- Girdling $(2 \mathrm{~mm})+50 \mathrm{ppm} \mathrm{GA}$

7- Girdling $(2 \mathrm{~mm})+100 \mathrm{ppm} \mathrm{GA}_{3}$

8- Girdling $(4 \mathrm{~mm})+50 \mathrm{ppm} \mathrm{GA}$

9- Girdling (4 mm) +100 ppm GA 3

The following parameters were recorded for both seasons: a- Vegetative growth parameters

1- Leaf area $\left(\mathrm{cm}^{2}\right)$ : Twenty mature leaves replicated three times were abscised in December, then leaf area $\left(\mathrm{cm}^{2}\right)$ was calculated at the end of each season by using cl-202 area meter.

2- Leaf carbohydrate was extracted and determined according to the method described by Malik and Singh (1980).

3- Leaf chlorophyll was recorded by using chlorophyll meter (Minolta, SPAD 502).

4- Leaf nutrient content: In September of each season leaf samples were taken randomly from non-fruiting and non-flashing terminal shoots, washed with tap water then with distilled water, dried at $70^{\circ} \mathrm{C}$ until constant weight, ground and finally digested. The digested solution was used to determine $\mathrm{N}, \mathrm{P}, \mathrm{K}$ percentage in leaves, which estimated by standard procedure according to Wilde et al. (1985).

b- Fruit quality parameters

The following parameters were considered: At harvest time (first week of January), the yield expressed in weight $(\mathrm{kg})$ and number of fruits per tree. Ten fruits were randomly collected from all sides of the trees under treatments for measuring the physical and chemical characterization: fruit dimensions [fruit length and diameter $(\mathrm{cm})$ ], peel thickness $(\mathrm{mm})$, fruit weight (g), total soluble solids percentage (TSS) using a hand refractometer, total titratable acidity as $\mathrm{mg}$ citric acid/100 $\mathrm{ml}$ of juice by titration against 0.1 normal sodium hydroxide in the presence of phenolphthalein as an indicator, TSS /acid ratio, ascorbic acid content ( $\mathrm{mg} / 100 \mathrm{ml}$ of juice) by titration against 2,6-dichlorophenol indophenol $(\mathrm{mg} / 100 \mathrm{ml})$ and total sugars $(\%)$ as described in the method of A.O.A.C. (1985).

\section{RESULTS AND DISCUSSION}

\section{Effects of Girdling and $\mathrm{GA}_{3}$ on Leaf Area, Carbohydrate and Chlorophyll Contents in the Leaves}

Table (1) indicates that during 2016 and 2017 seasons, all treatments increased leaf area. The highest significant values of leaf area were produced by $100 \mathrm{ppm} \mathrm{GA}$, girdling $2 \mathrm{~mm}+100 \mathrm{ppm} \mathrm{GA}$ and girdling $4 \mathrm{~mm}+100 \mathrm{ppm}$ $\mathrm{GA}_{3}$ in both seasons. Concerning leaf area, no significant differences appeared during summer and autumn in both seasons. On the other hand, there were significant differences by using some combination of treatments, the use of

Egyptian J. Desert Res., 71, No. 1, 75-97 (2021) 
girdling $2 \mathrm{~mm}+100 \mathrm{ppm} \mathrm{GA}_{3}$ in autumn of the first season followed by girdling $4 \mathrm{~mm}+100 \mathrm{ppm} \mathrm{GA}_{3}$ in Autum of the second season. Sharma and Ananda (2004) found that, applications of $\mathrm{GA}_{3}$ at $10-40 \mathrm{ppm}$ and $\mathrm{GA}_{3}$ at 10 $\mathrm{ppm}+$ benzyladenine (BA) at $5 \mathrm{ppm}$ resulted in a significantly high increase in vegetative growth of apples over the control. Also, it was reported that girdling application increased leaf area (Bahlool et al., 2000 and Said et al., 2003). In addition, Yilmaz et al. (2018) indicated that girdling significantly increased total chlorophyll compared to untreated trees.

Results in table (1) clearly indicate that the maximum recorded carbohydrates content in leaves was 12.24 and $12.89 \%$ in 2016 and 2017, respectively, using $50 \mathrm{ppm} \mathrm{GA}_{3}$ in the second season and girdling $4 \mathrm{~mm}+100$ ppm $\mathrm{GA}_{3}$ during both seasons, compared with all treatments. No significant differences in the total carbohydrates was observed between summer and autumn treatments in both seasons. Hence, combined application of different treatments gave the highest carbohydrates content with girdling $4 \mathrm{~mm}+100$ ppm $\mathrm{GA}_{3}$ in autumn in the first season and girdling $4 \mathrm{~mm}+100 \mathrm{ppm} \mathrm{GA} 3$ in both seasons. Girdling increased the carbohydrate concentration in Vitis vinifera L. (Roper and Williams, 1989). On the other hand, Vemmos et al. (2012) found that girdling increased carbohydrates, particularly starch in pistachio shoots. Also, Jordan et al. (2001) reported that starch level increased in leaves and shoots of girdled peach trees. Finally, Chun et al. (2003) on 'Anna' apple found that girdling increased the accumulation of carbohydrate content in the upper part of girdle.

Regarding chlorophyll content in the leaves, it is observed that significant differences were among the treatments, since the highest value was obtained with girdling $4 \mathrm{~mm}+100 \mathrm{ppm} \mathrm{GA} 3$ during the two studied seasons. On the other hand, there were significant differences in summer treatments, which gave the highest values for the two seasons. However, the highest value was obtained with autumn treatments in the second season. Regarding the combination between treatments, the highest significant value was obtained with girdling $4 \mathrm{~mm}+100 \mathrm{ppm} \mathrm{GA}_{3}$ in the two seasons when compared with any other treatments. For treatments in combination, the data of both seasons 


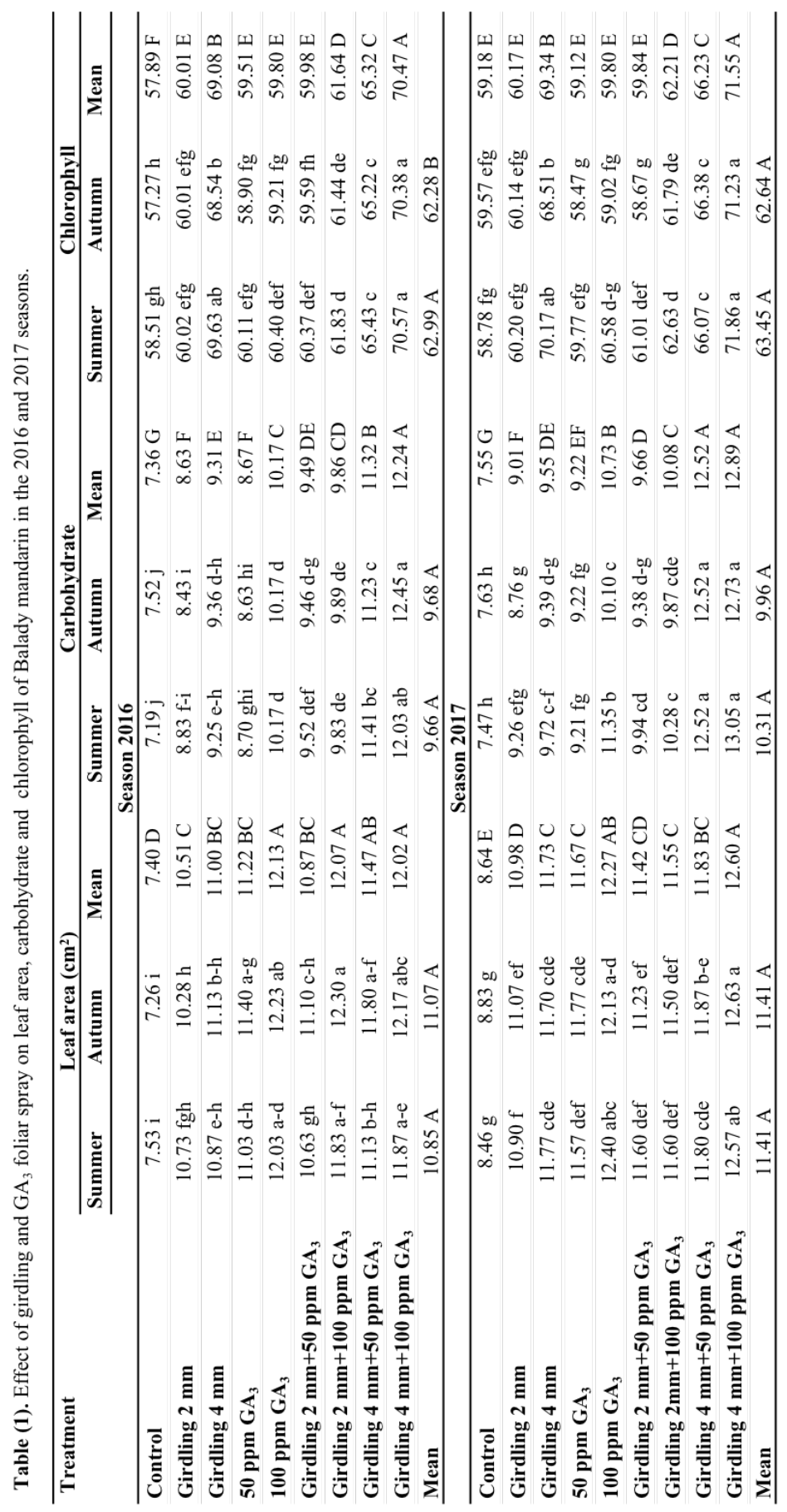

Egyptian J. Desert Res., 71, No. 1, 75-97 (2021) 
showed that the highest value was obtained with girdling $4 \mathrm{~mm}$ and girdling $4 \mathrm{~mm}+100 \mathrm{pp} \mathrm{GA}$. Additionally, results obtained in the first season showed that the highest value was in summer. While, in the second season, there was no significant effect, when compared with the control. In addition, Mostafa and Saleh (2006) indicated that girdling induced increase in total chlorophyll significantly, compared to control. In addition, several authors have proposed that total leaf carbohydrate content and starch increased as a result of girdling (Rivas et al., 2008). It may be due to the accumulation of chlorophyll content and increased photosynthesis in the girdled branch. Chlorophyll fluorescence has become one of the most powerful and widely used techniques available to plant physiologists and ecophysiologists. In addition, Yilmaz et al. (2018) indicated that girdling significantly increased total chlorophyll.

\section{Ffects of Girdling and $\mathrm{GA}_{3}$ on Nitrogen, Phosphorus and Potassium Contents in the Leaves}

As shown in table (2), leaf nitrogen content reached its maximum levels at summer and autumn 2017 and 2018 seasons. However, treatment girdling $4 \mathrm{~mm}+100 \mathrm{ppm} \mathrm{GA} 3$ gave the best leaf nitrogen content followed by $100 \mathrm{ppm} \mathrm{GA} \mathrm{A}_{3}$ in both seasons during this study, compared to all treatments.

Interaction data showed that, leaf nitrogen (\%) was the highest value in case of leaves of trees that have treated with girdling $4 \mathrm{~mm}+100 \mathrm{ppm} \mathrm{GA}_{3}$ in summer in the first and second seasons and only in autumn in the second season, respectively.

The data presented in table (2) show that the highest significant leaf phosphorus (\%) was recorded with girdling $4 \mathrm{~mm}+100 \mathrm{ppm} \mathrm{GA}_{3}$ in the first season and girdling $4 \mathrm{~mm}+50 \mathrm{ppm} \mathrm{GA}$ in the second season. In addition, significant increases in leaf phosphorus were recorded by summer treatment in both seasons and autumn in the second season only. Regarding the interaction, the highest values of leaf phosphorus content were obtained with girdling $4 \mathrm{~mm}+50 \mathrm{ppm} \mathrm{GA}_{3}$ in summer in both seasons and in autumn in the second season. In addition, control was the lowest leaf phosphorus content.

Results in table (2) show that leaf potassium (\%) was significantly influenced by different treatments; girdling $2 \mathrm{~mm}+50 \mathrm{ppm} \mathrm{GA}_{3}$ in the first season and girdling $2 \mathrm{~mm}+100 \mathrm{ppm} \mathrm{GA}_{3}$ in the second season. Data also indicated that, trees at autumn gave the highest significant values in the first season. Meanwhile, no significant values were observed in both summer and autumn in the second season, compared with all treatments.

The obtained data revealed that girdling $2 \mathrm{~mm}+50 \mathrm{ppm} \mathrm{GA}_{3}$ in the first season and girdling $2 \mathrm{~mm}+100 \mathrm{ppm} \mathrm{GA}$ in the second season reflect significant increases in leaf potassium content of leaves, compared with all treatments. In the other side, it was found that girdling improved $\mathrm{N}$ and $\mathrm{K}$ content in leaves. According to Rivas et al. (2006), the productivity of Fortune and Clausellina mandarins can be improved by girdling. Cimó et al. (2013) 


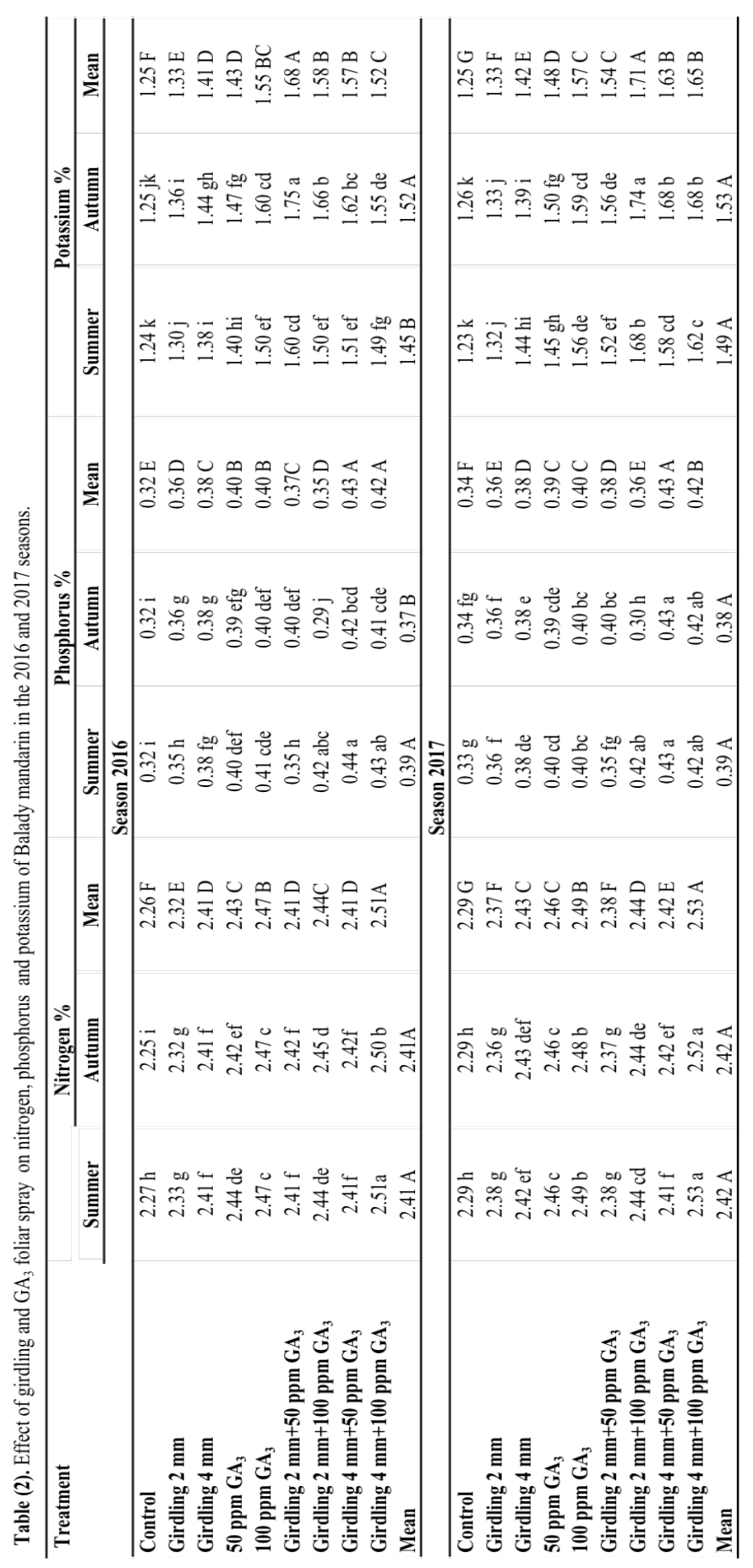

Egyptian J. Desert Res., 71, No. 1, 75-97 (2021) 
reported that girdling treatments decreased $\mathrm{N}, \mathrm{P}, \mathrm{K}, \mathrm{Ca}$ and $\mathrm{Mg}$ concentrations in the leaves of citrus and reduced the levels of all measured micronutrients.

\section{Effects of Girdling and $\mathrm{GA}_{3}$ on Fruit Size and Thickness on Balady Mandarin}

It is clear from table (3) that fruit size (length and diameter) has shown that there was a significant increase in in fruit length, diameter and thickness of fruit. Effects of trunk girdling and gibberellic acid on the fruit length was maximum giving fruit length of $6.48 \mathrm{~cm}$, recorded in plants treated with girdling $4 \mathrm{~mm}$ alone in the first season. While, girdling $4 \mathrm{~mm}+100 \mathrm{ppm} \mathrm{GA}$ recorded the highest values $(5.87 \mathrm{~cm})$ of fruit length in the second season. However, the data cleared that in both seasons, no significant differences between summer and autumn was shown in the first season but in the second season, the the highest value (5.46) was observed in autumn. Regarding interactions on fruit length, data revealed that girdling $4 \mathrm{~mm}$ or girdling 4 $\mathrm{mm}+100 \mathrm{ppm} \mathrm{GA}{ }_{3}$ gave the highest values $(6.43,6.53$ and $5.80,5.93$ in summer and autumn in the first and second seasons, respectively). Sousa et al. (2005) found that, girdling increased fruit length of pear trees.

The results in table (3) show that the highest fruit diameter was significantly affected by girdling $2 \mathrm{~mm}+100 \mathrm{ppm} \mathrm{GA}$, followed by $50 \mathrm{ppm}$ $\mathrm{GA}_{3}$ in the first season and girdling $4 \mathrm{~mm}$ in the second season, compared to control. Also, the data indicated that no significant differences were observed between summer and autumn treatments on fruit diameter in the second season. The treatments in the first autumn gave the best value for increasing fruit diameter.

The interaction on fruit diameter was significant, where, as the application of girdling $2 \mathrm{~mm}+50 \mathrm{ppm} \mathrm{GA}$ and $100 \mathrm{ppm} \mathrm{GA}$ in autumn of both seasons, respectively. The increase in fruit size might be pertained to the fact that gibberellins indirectly affected the level of auxin that ultimately caused cell elongation by enlargement of vacuoles and loosening of cell wall after increasing its palatability. Also, girdling grapevines increases carbohydrate concentration above girdle and resulted in larger berries as the transport of sugars from leaves to the root system (Roper and Williams, 1989). The increase in fruit size by girdling also reported Davie et al (1995) in avocado, Sousa et al (2008) in 'Rocha' pear, Reginato and Mesa (2011) in 'Castlebrite' apricot and Murakami (2012) in 'Rainbow Red' kiwifruit. Khandaker et al (2011) found that girdling branches of wax jambu (Syzygium samarangense) produced the highest fruit length and diameter.

Data the table (3) clear that in both seasons, the highest peel thickness was obtained by the control treatments $(0.36-0.37)$, while, the lowest was obtained by girdling $4 \mathrm{~mm}+100 \mathrm{ppm} \mathrm{GA}_{3}(0.25-0.24)$ in both seasons. On the other hand, no significant differences were observed between summer and autumn treatments in both seasons. Regarding interaction effects, the obtained data revealed that girdling $4 \mathrm{~mm}+100 \mathrm{ppm} \mathrm{GA}$ gave the lowest significant 


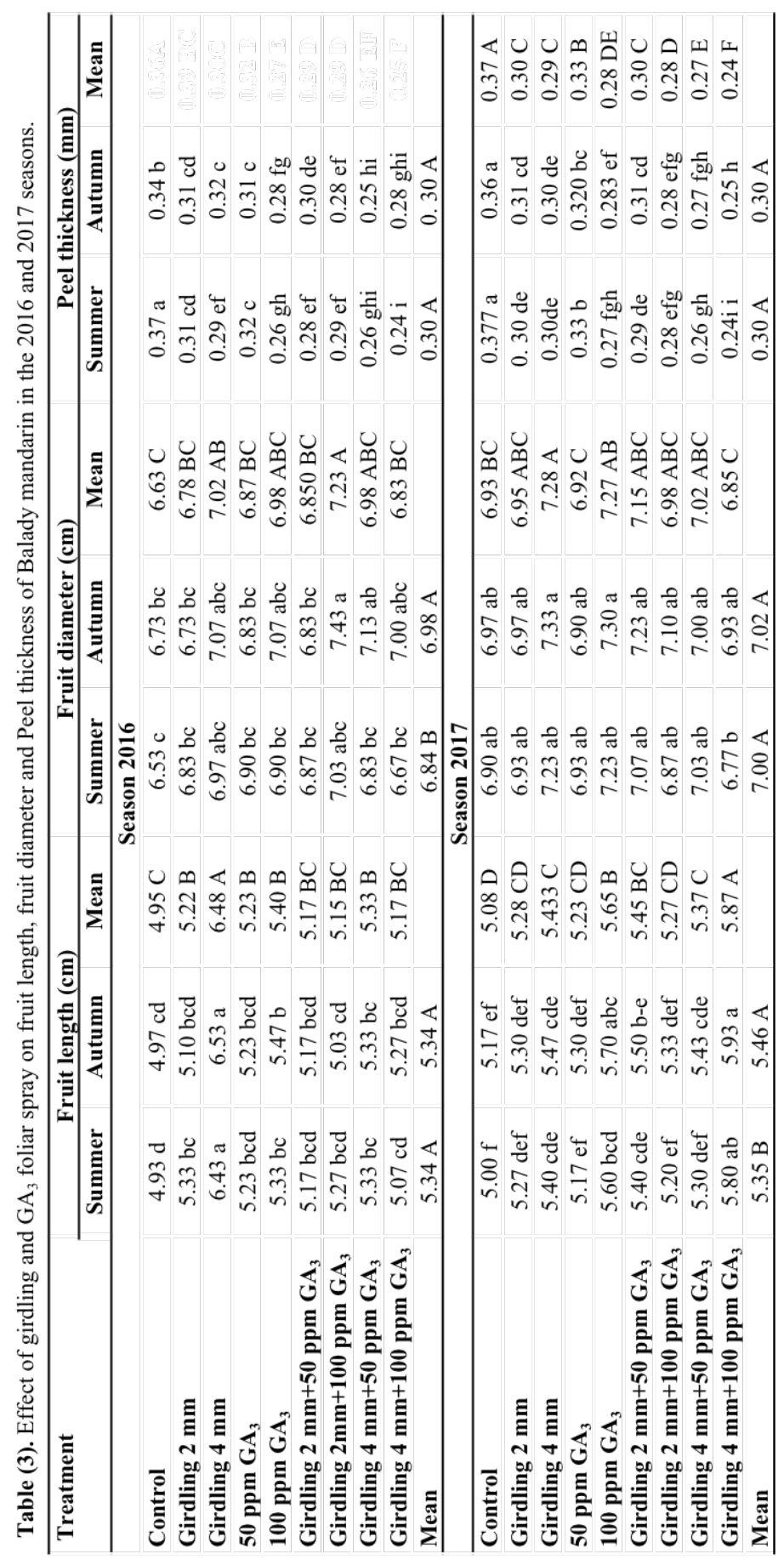

Egyptian J. Desert Res., 71, No. 1, 75-97 (2021) 
values $(0.24-0.24)$ in both seasons. The same has been reported by Elotmani et al. (1993), who found an increase of peel weight in absolute value but not relatively to whole fruit weight after auxin treatment. Fruits harvested from trees treated with girdling were significantly larger than fruits from control trees, which indicated that the application of girdling increased fruit size (Mostafa and Saleh, 2006 and Rivas et al., 2007). The increasing effect of gibberellic acid combined with girdling on weight and size of bunches and berries agree with several authors (Roper and Williams, 1989). It was observed a synergic action between crop set and gibberellic acid, enhancing effects on berry size. Also, Og uzhan et al. (2015) found that vines had girdled to accomplish for enhancing yield as well as cluster weight, cluster length and width of Red Globe grapevine.

\section{Effects of Girdling and $\mathrm{GA}_{3}$ on Number of Fruits, Fruit Weight and Yield on Balady Mandarin}

Data in table (4) indicated that there was a significant difference between the treatments and the control. It could be observed that the maximum value of number of fruit/tree was related to the treatment of girdling 4 $\mathrm{mm}+100 \mathrm{ppm} \mathrm{GA}_{3}$ as compared with control during both seasons. Treatments in summer have given the maximum values of number of fruits/tree in both seasons. On the other hand, the results indicated that using combination between girdling and application of $\mathrm{GA}_{3}$, the maximum value with girdling 4 $\mathrm{mm}+100 \mathrm{ppm} \mathrm{GA} 3$ was in summer during the two seasons. Girdling generally has a positive effect on fruit size if not accompanied by an increase in fruit number (Goren et al., 2003). Similarly, Mohamed (2011) found that spraying Washington Navel orange with $\mathrm{GA}_{3}$ at concentration of $10 \mathrm{ppm}$ at 3 times (beginning of flowering, full bloomming and after fruit set), gave the maximum fruit retention percentage and yield/ tree. Girdling is a practice used in order to control the excessive vegetation and thereby improving the crop yield due to increase of fruit set and fruit size (Raffo et al., 2011). The increase in fruit yield with the girdling also reported by Chanana and Gill (2008) in grapes, and Huang et al. (2012) in 'Nuomici' and 'Guiwei' cultivars of litchi. According to Rivas et al. (2006), the productivity of Fortune and Clausellina mandarins can be improved by girdling. Similarly, trunk girdling has been shown to increase fruit set in many crops, including apple [Malus domestica Borkh.] (Hoying and Robinson, 1992), kiwifruit [Actinidia chinensis Planch.] (Boyd and Barnett, 2011) and Fuyu persimmon [Diospyros kaki L.] (Choi et al., 2010).

Significantly maximum fruit weight (145.0-149.5 g) was obtained with girdling $4 \mathrm{~mm}+100 \mathrm{ppm} \mathrm{GA}$ treatment. While, minimum fruit weight was 132.7 - $135.7 \mathrm{~g}$ of control treatment. Both treatments of autumn significantly increased the fruit weight. The highest values of fruit weight was recorded in the second autumn treatment in both seasons, whereas the lowest 


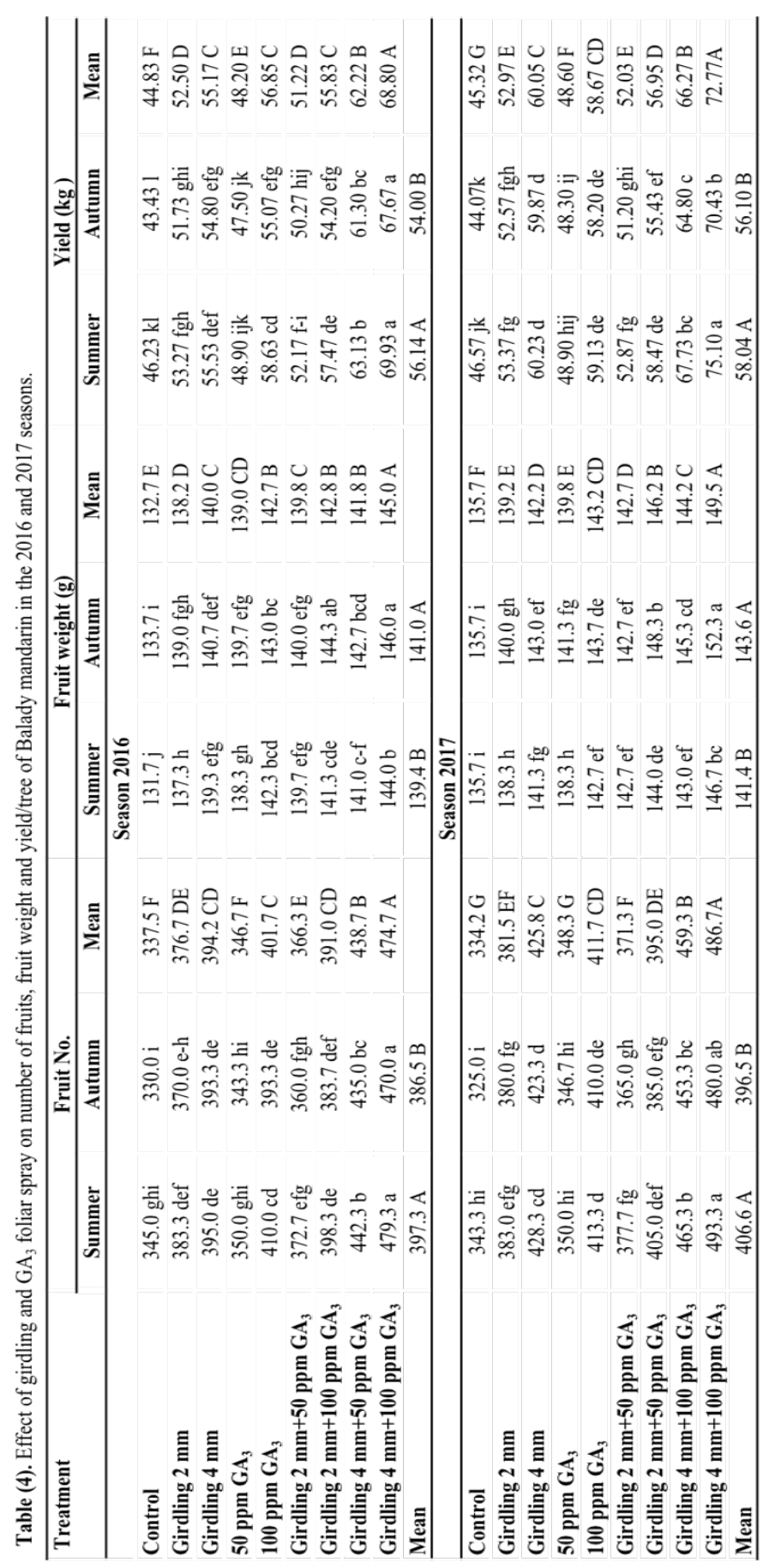

Egyptian J. Desert Res., 71, No. 1, 75-97 (2021) 
amount was obtained during the first girdling. It might be due to the fact that growth regulators as $\mathrm{GA}_{3}$ show indirect effect through auxin stimulation, which lead to the increase in fruit weight as reported in the study conducted by Wo et al. (2001) on 'Fujiminori' grapes. Thus, the results of the present study could agree with the finding of Mostafa and Saleh (2006), who reported that girdling alone or with potassium spray increases the fruit size and fruit weight in Balady mandarin orange. Fruit weight is an important quality parameter of fruit production. Bark ringing or girdling significantly increases the fruit weight as well as yield (Hossain et al., 2007).

Table (4) reveals that the best results were obtained with girdling 4 $\mathrm{mm}+100 \mathrm{ppm} \mathrm{GA}$, which gave the maximum yield of mandarin trees $(68.80$ $-72.77 \mathrm{~kg} / \mathrm{tree})$. On the other hand, treatments with girdling $4 \mathrm{~mm}+100 \mathrm{ppm}$ $\mathrm{GA}_{3}$ have given the maximum yield in summer $(56.14-58.04 \mathrm{~kg} / \mathrm{tree})$ and autumn (67.67-70.43 kg/tree) in the two seasons. On the other hand, the fruit yield per tree with girdling $4 \mathrm{~mm}+100 \mathrm{ppm} \mathrm{GA}_{3}$ gave the maximum values in the first (69.93-67.67 kg/tree) and second (75.10-70.43 kg/tree) seasons, respectively. In this respect, girdling application increased yield by about $25-$ $37 \%$ as reported by Dawood et al. (2001). On the other hand, Rivas et al. (2006) found increase in fruit retention percentage and yield of most of citrus species by girdling. Girdling can improve carbohydrate availability to fruits and as consequently lead to an increase in fruit-set and yield as well as number of fruits (Goren et al., 2003). On the other hand, Abu-Zahra (2010) reported that $\mathrm{GA}_{3}$ and $\mathrm{GA}_{3}$ + girdling was effectively influenced the yield of grapevine for the commercial production of Thompson seedless grapes.

\section{Effects of Girdling and $\mathrm{GA}_{3}$ on Juice Chemicals Constitute of Balady Mandarin Fruits}

Results in table (5) concerning the soluble solids content in the fruit juice, treatments significantly increased this parameter especially with girdling $4 \mathrm{~mm}+100 \mathrm{ppm} \mathrm{GA}$, which increased of the TSS\% as compared with the other treatments in both seasons. Also, there was no significant differences between summer and autumn as compared with control during the two seasons. Meanwhile, using girdling $4 \mathrm{~mm}+100 \mathrm{ppm} \mathrm{GA}_{3}$ has given the highest significantl values in both seasons. On the other hand, the control gave the lowest values in the two seasons. The results obtained in the present investigation are also supported by the findings of Mishra et al. (2003) and Nawaz et al. (2008) in Kinnow mandarin. The results obtained in the present study agree with those described in a previous report by Rather et al. (2011), who reported that girdling and growth regulator application are attractive practices to improve berry ripening and berry quality in grape $\mathrm{cv}$. Perlette. The increase in TSS in the present study is in line with the findings of Huang et al. (2012) in 'Nuomici' and 'Guiwei' litchi. Kaur et al. (2008) also reported 


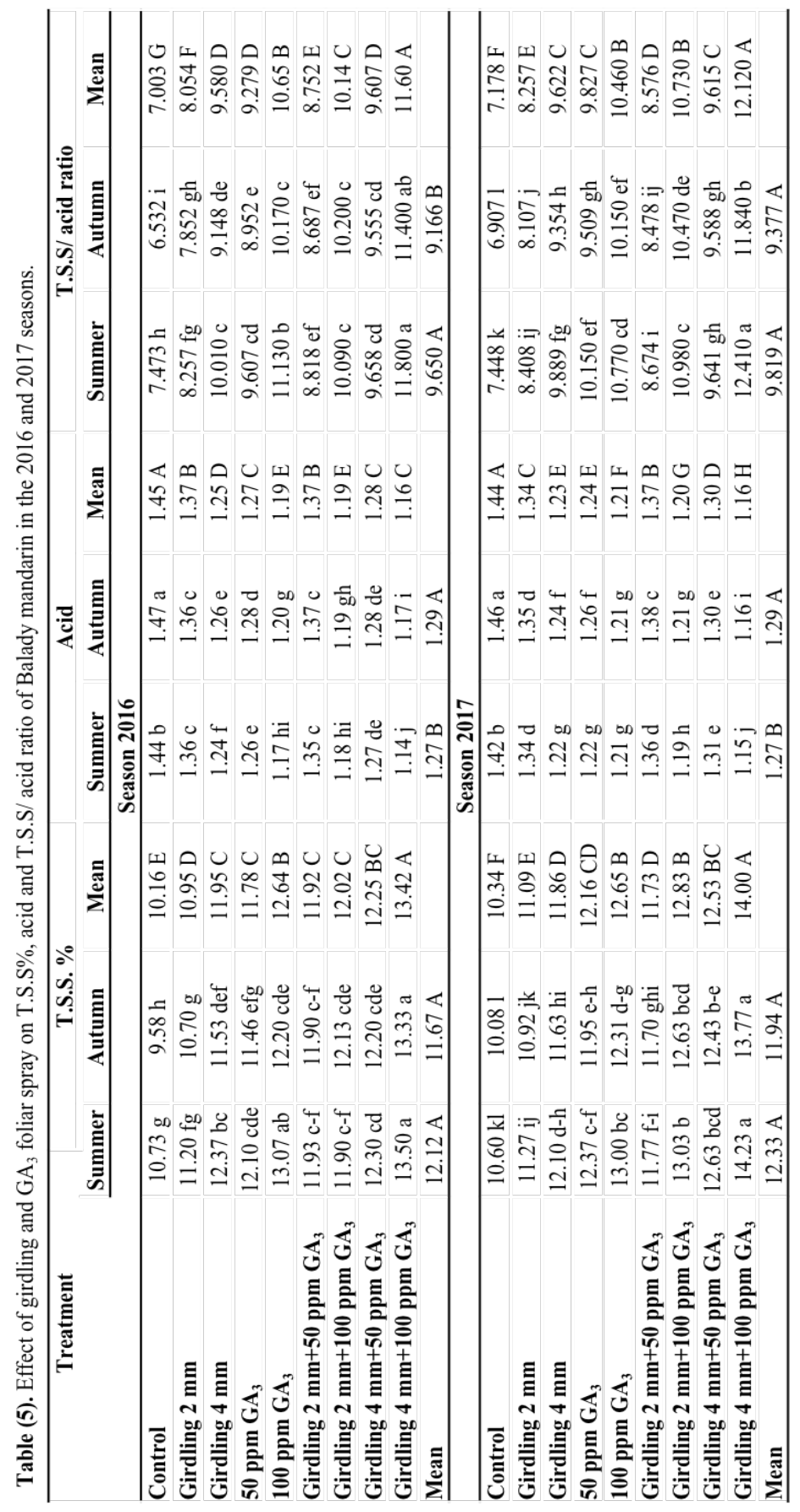

Egyptian J. Desert Res., 71, No. 1, 75-97 (2021) 
similar findings with the application of $\mathrm{GA}_{3}+$ girdling in 'Perlette' grapes and Nawaz et al. (2008) in Kinnow.

For in the fruit juice acidity percentage, results in table (5) reveal that, the averages values of total acidity (\%) gave the highest values in the trees treated as control in 2016 and 2017 seasons, respectively. Regarding to acidity percentage, it recorded the highest significantly value of different treatments in autumn during both seasons.

Regarding interaction, data demonstrate that, total acidity (\%) was the highest with control treatments in two seasons. In addition, the data of the girdling $4 \mathrm{~mm}+100 \mathrm{ppm} \mathrm{GA}_{3}$ showed the lowest significant values for acidity percentage. However, different results were obtained when CPPU was used affecting the chemical composition of the fruit (Harrel and Williams., 1987 and Leão et al., 2000). Acidity was also found to decreased with the girdling by Fujishima et al. (2005) in 'Pione' grapes, Huang et al. (2012) in 'Nuomici' and 'Guiwei' cultivars of litchi. Kaur et al. (2008) also observed similar trend of reduction of acidity with the use of $\mathrm{GA}_{3}$ and girdling.

Regarding TSS/acid ratio, results showed significant differences between treatments in both seasons, since the maximum TSS: acid ratio (11.60-12.12) was observed under treatment of girdling $4 \mathrm{~mm}+100 \mathrm{ppm} \mathrm{GA} 3$ in the two studied seasons as compared to control (7.003-7.178). Also, maximum TSS: acid ratio in this respect was obtained when trees were treated in summer and summer and autumn in the first and second seasons, respectively (9.65-9.82 and 9.38). On the other hand, the results indicated that using the combination between girdling and $\mathrm{GA}_{3}$ application has given the maximum TSS: acid ratio (11.80 - 12.41) by using girdling $4 \mathrm{~mm}+100 \mathrm{ppm}$ $\mathrm{GA}^{3}$ in summer for the first and second seasons, respectively. These results support the earlier findings of Singh et al. (2002) in 'Royal Delicious' apple and $\mathrm{Wu}$ and Lin (2003) in loquat in response to the application of growth regulators. Crupi et al. (2016) mentioned that girdling was able to improve the soluble solids content over titrable acidity (SSC /TA), a ratio strictly related to the quality perception by the consumer.

The data given in table (6) show that the highest values of vitamin $C$ was obtained when trees were treated with girdling $4 \mathrm{~mm}+100 \mathrm{ppm} \mathrm{GA} 3$ in the two studied seasons. Also, the lowest values of vitamin $\mathrm{C}$ were obtained when trees were treated with girdling $2 \mathrm{~mm}$ and $50 \mathrm{ppm} \mathrm{GA}_{3}$ in the first and second seasons, respectively, compared with control. Also, no significant differences were recorded between summer and autumn during the two seasons. On the other hand, the highest vitamin $\mathrm{C}$ value was obtained by using the combination of girdling $4 \mathrm{~mm}+100 \mathrm{ppm} \mathrm{GA}$, girdling $2 \mathrm{~mm}+100 \mathrm{ppm}$ $\mathrm{GA}_{3}$ and girdling $4 \mathrm{~mm}$ in the first and second seasons, respectively. The results obtained in the present investigation are also supported by the findings of Sharma et al. (2003), Kachave and Bhosale (2009) in Kagzi lime and Nawaz et al. (2008) in Kinnow mandarin. Zhao et al. (2013) stated that vitamin $\mathrm{C}$ content in apple in-creased with girdling. 


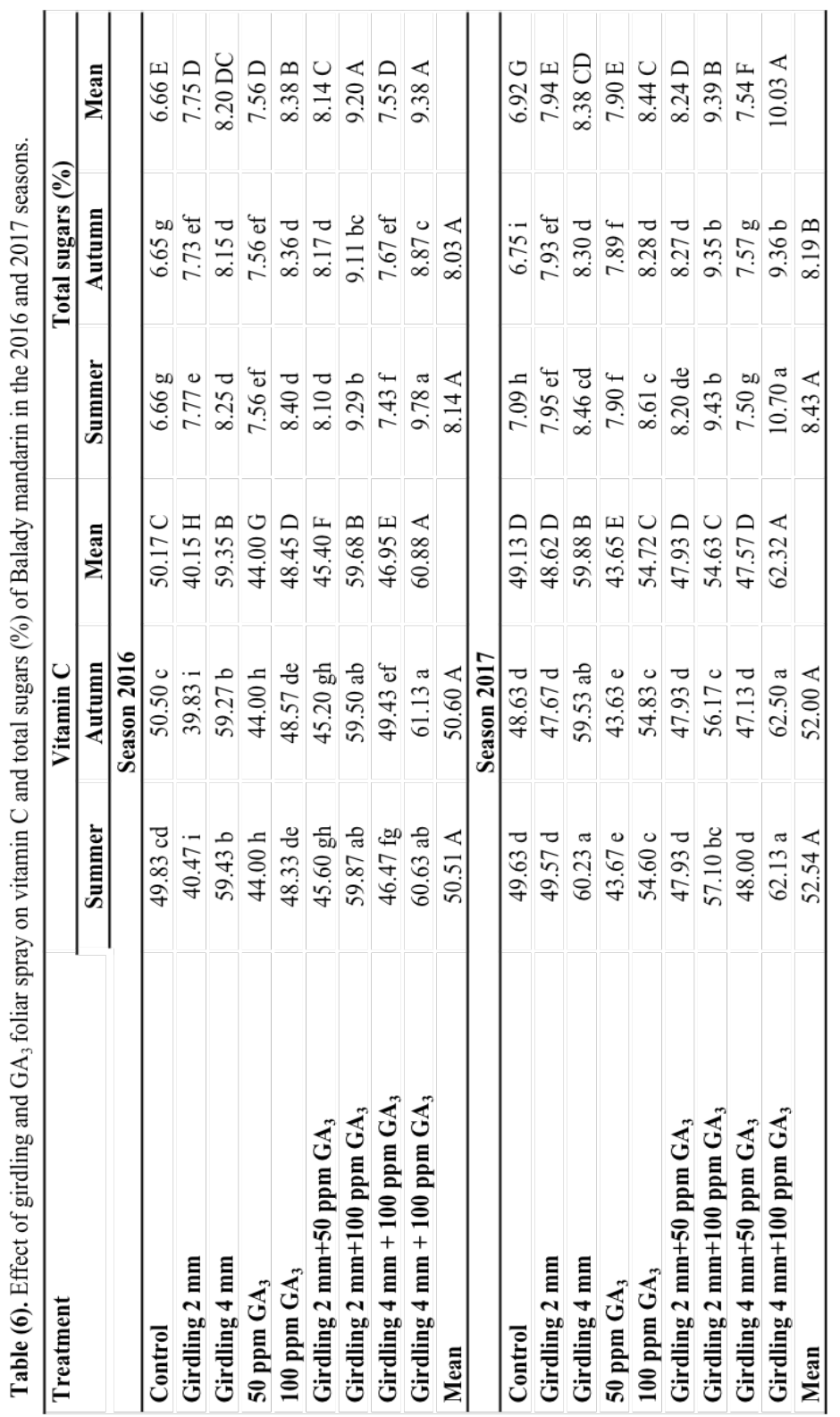

Egyptian J. Desert Res., 71, No. 1, 75-97 (2021) 
Data represented in table (6) show the initial increase in total sugars with girdling and increased application of $\mathrm{GA}_{3}$ in both seasons, compared with control. Maximum total sugars was recorded with girdling $4 \mathrm{~mm}+100 \mathrm{ppm}$ $\mathrm{GA}_{3}$ in the two seasons. On the contrary, the control trees produced significantly the minimum total sugars in the two tested seasons. The highest value of total sugars was obtained with girdling $4 \mathrm{~mm}+100 \mathrm{ppm} \mathrm{GA} 3$ in summer in the two seasons. Roussos and Anastassios (2011) reported that sucrose, glucose and fructose concentrations were the highest in fruits from girdled scaffold of mandarin trees. The results agree with Abd El- Wahab (2006), Abd El-Razek et al. (2010), Abu-Zahra (2010) and Abu-Zahra and Salmeh (2012), who found that trunk girdling increased total sugar and enhanced berry colorations. Verreynne et al. (2001) reported that girdling enhanced total soluble solids and total sugar content in Marisol' Clementine's. Fruits from the girdle branch yielded the higher amount of total sugars which may be due to carbohydrate availability and the high starch content in the upper part of girdle. The present study is in accordance with the findings of Wahdan et al. (2011) on 'Succary Abaid'mango in response to $\mathrm{GA}_{3}$ and NAA application. The increase in total sugars content of fruits by girdling was also noted by Chanana et al. (2006) in 'Florda Prince'cultivar of peach. Kaur et al. (2008), also noticed the increase in reducing sugars of 'Perlette' grapes with $\mathrm{GA}_{3}$ application and girdling.

\section{REFERENCES}

A.O.A.C. (1985). In: "Official Methods of Analysis" $12^{\text {th }}$ ed. Association of Official Analytical Chemists. Washington Press, pp. 574-575.

Abd El-Rahman, A.S. (2007). Effect of boron, berry thinning, girdling and GA3 on yield and fruit quality of ruby seedless grapes. $\mathrm{PhD}$ thesis, Pomology Dept., Fac. Agric., Cairo Univ., Egypt.

Abd El-Razek, E, D. Treutter, M.M.S. Saleh, M. El-Shammaa, A.A. Fouad, N. Abdel- Hamid and M. Abou-Rawash (2010). Effect of defoliation and fruit thinning on fruit quality of 'Crimson Seedless' grape. Res. J. Agri. Biol. Sci., 6: 289-295.

Abd El-Wahab, M.A. (2006). An attempt towards improving bunch quality through berry thinning and trunk girdling treatments in Black Monukka grape. J. Agric. Sci., Mansoura Univ., 31 (10): 6577- 6593.

Abu-Zahra, T.R. (2010). Berry size of thompson seedless as influenced by the application of gibberellic acid and cane girdling. Pak. J. Bot., 42: 1755-1760.

Abu-Zahra, T.R. and N.M. Salameh (2012). Influence of gibberellic acid and cane girdling on berry size of black magic grape cultivar Middle-East. J. Sci., Res., 11 (6): 718-722. 
Ahmed, W., K. Ziaf, M.A. Nawaz, B.A. Saleem and C.M. Ayyub (2007). Studies on combining ability of citrus hybrids with commercial indigenous cultivars. Pak. J. Bot., 39 (1): 47-55.

Ashraf, M.Y., M. Ashraf, M. Akhtar, K. Mahmood and M. Saleem (2013). Improvement in yield, quality and reduction in fruit drop in Kinnow (Citrus reticulata Blanco) by exogenous application of plant growth regulators, potassium and zinc. Pak. J. Bot., 45: 433-440.

Bahlool, S., B. Shahin and H. Kabeel (2000). Effect of some cultural practices on flower bud formation, fruit set and yield of "Le-Conte" pear trees. J. Agric., Mansoura Univ., 25 (2): 975-985.

Boyd, L.M. and A.M. Barnett (2011). Manipulation of whole-vine carbon allocation using girdling, pruning, and fruit thinning affects fruit numbers and quality in kiwifruit. Hortscience, 46: 590-595.

Brar, H.S., Z. Singh, E. Swinny and I. Cameron (2008). Girdling and grapevine leaf roll associated viruses affect berry weight, color development and accumulation of anthocyanins in 'Crimson Seedless' grapes during maturation and ripening. Plant Science, 175: 885-897.

Chanana, Y.R. and K.S. Gill (2006). Impact of girdling, thinning and their combination of quality and maturity in Florda Prince peach. Indian J. Hort., 63 (1): 27-30.

Chanana, Y.R. and M.I.S. Gill (2008). High quality grapes can be produced in Punjab. Acta Hort., 785: 85-86.

Choi, S.T., W.D. Song, D.S. Park, S.M. Kang (2010). Effect of different girdling dates on tree growth, fruit characteristics and reserve accumulation in a late-maturing persimmon. Scientia Horticulturae, 126: $152-155$.

Chun, Y.L., W. David and E.G. Eliezer (2003). Girdling affects carbohydraterelated gene expression in leaves, bark and roots of alternate-bearing citrus trees. Ann. Bot., 92: 137-143.

Cimò, G., R.L. Bianco, P. Gonzalez, W. Bandaranayake, E. Etxeberria and J.P. Syvertsen (2013). Carbohydrate and nutritional responses to stem girdling and drought stress with respect to understanding symptoms of Huang longbing in Citrus. Hort Science, 48 (7): 920-928.

Crupi P., D. Antonacci, M. Savino, G. Rosalinda, R. Perniola and A. Colleta (2016). Girdling and gibberellic acid effects on yield and quality of a seedless red table grape for saving irrigation water supply. European Journal of Agronomy, 80: 21-31.

Davie, S.J., P.J.C. Stassen, M. Walt, Van-Dar and B. Snijder (1995). In: "Girdling Avocado Trees for Improved Production". South African Avocado Growers Association Year Book, 18: 51-53.

Dawood, S.A., M.S. Meligy and M.M. El-Hamady (2001). How to regulate cropping in Balady Mandarin trees (B) using girdling and GA3. Minufiya J. Agric. Res., 26 (3): 883-894.

Egyptian J. Desert Res., 71, No. 1, 75-97 (2021) 
Elotmani, M., M. Agusti, M. Aznar and V. Almela (1993). Improving the size of Fortune mandarin fruits by the auxin 2,4-DP. Sci. Hort., 55: 283290.

El-Sese, A.M.A. (2005). Effect of gibberellic acid (GA) on yield and fruit characteristics of Balady mandarin. Assiut J. Agric. Sci., 36 (1): 23 35.

Fujishima, H., M. Shiraishi, S. Shimomura and Y. Horie (2005). Effect of girdling on berry quality on 'pione' Grapevine. Hort. Res., 4 (3): 313318.

Goren, R., M. Huberman and E.E. Goldschmidt (2003). Girdling: physiological and horticultural aspects. Horticultural Reviews, 30: 136.

Hanafy, A.A., M.K. Khalil, A.M. Abd EI-Rahman and A.M. Nadia Hamed (2012) Effect of zinc, tryptophan and indole acetic acid on growth, yield and chemical composition of Valencia orange trees. Journal of Applied Sciences Research, 8 (2): 901-914.

Harrell, D.C. and L.E. Williams (1987). The influence of girdling and gibberellic acid application at fruit set on ruby seedless and Thompson seedless grapes. American Journal of Enology and Viticulture, 38 (2): 83-88.

Hossain, A.B.M.S., F. Mizutani, J.M. Onguso, A.R. Shereif and H. Yamada (2007). Inhibiting peach-trees growth with abscisic acid, hinokitiol and tropolone applied to partially ringed bark strips. J. Hort. Sci. Biotechnol., 82: 175-178.

Hoying, S.A. and T.L. Robinson (1992). Effects of chain saw girdling and root pruning of apple trees. Acta Hort., 322: 167-172.

Huang, D., S. Liu, X. Zhou, D. Qian, C. Wu and Y. Xu (2012). The effect spiral girdling on the fruit setting and development of young litchi trees. Acta Hort., 928: 145-150.

Ibrahim, M.M., A.O. Mohamed, A.H. Mohamed and A.A. Omar (2016). Effect of some girdling treatments on fruiting behaviour and physiochemical properties of Washington Navel Orange trees. J. Agri. Vet. Sci., 9: 58-65.

Jordan, M.O., L. Gomez and S. Mediene (2001). Regulation of N uptake in young peach trees in relation to the management of carbon and nitrogen stores. Acta Hort., 564: 63-70.

Kachave, D.B. and A.M. Bhosale (2009). Effect of PGR and micronutrients on certain quality attributes of Kagzi lime (Citrus aurantifolia Swingle). International Journal of Agricultural Sciences, 5 (1): 50-52.

Kaur, N., J.S. Josan and S.K. Thatai (2008). Influences of gibberellic acid, girdling and brushing on quality aspects of grapes cv. Perlette. Indian J. Hort., 65 (1): 113-115.

Khandaker, M.M., A.S. Hossain, N. Osman and A.N. Boyce (2011). Application of girdling for improved fruit retention, yield and fruit 
quality in Syzygium samarangense under field conditions. International Journal of Agriculture and Biology, 13: 18-24.

M.A.L.R. (2015). Ministry of Agriculture and Land Reclamation Economic Affairs, Egypt. Agric. Directorates of Governorates, 2: 314.

Mahouachi, J., D.J. Iglesias, M. Agustí, and M. Talon (2012). Delay of early fruitlet abscission by branch girdling in citrus coincides with previous increases in carbohydrate and gibberellin concentrations. J. Plant Growth Regul., 58 (1): 15-23.

Malik, C.P. and M.B. Singh (1980). In: "Plant Enzymology and HistoEnzymology". A text manual. Kalyani Publishers, New Delhi, India.

Mishra, R.S., S.K. Singh, H.C. Sharma, A.M. Goswami and B. Pratap (2003). Effect of micronutrients and rootstocks on fruit yield and quality of Kinnow under high density planting. Indian Journal of Horticulture, 60 (2): 131-134.

Mohamed, M.I. (2011). Effect of some nitrogen fertilization and growth regulators treatments on growth and fruiting of orange trees. $\mathrm{PhD}$. Thesis, Fac. Agric., Zagazig Univ., Egypt.

Mostafa, E.A.M. and M.M.S. Salah (2006). Response of Balady mandarin trees to girdling and potassium sprays under sandy soil conditions. Res. J. Agric. Bio. Sci., 2 (3): 137-141.

Murakami S. (2012). Effect of girdling methods on fruit quality in 'Rainbow Red' kiwifruit (Actinida chinensis). Hort. Res., 11 (2): 281-287.

Nawaz, M.A., A. Waqar, A. Saeed and M.M. Khan (2008). Role of growth regulators on preharvest fruit drop, yield and quality in Kinnow mandarin. Pak. J. Bot., 40: 1971- 1981.

Og uzhan, S., T. Turcan, E. Adnan, E. Kacar and A.T. Altindis (2015). Response of "Red Globe" (Vitis vinifera L.) to cane girdling. BIO Web of Conferences, 5: 1-4.

Raffo, M.D., P. Calvo, V. De Angelis, L. Ma nueco, S. Ziaurriz and F. Menni (2011). Effects of trunk girdling, on fruit productions, fruit size, and tree vigor on 'Bartlett' pears in Rio Negroand Neuquen Valley, Argentina. Acta Hort., 909: 645-650.

Rather, J.A., S.H. Wani, A. Haribhushan and Z.A. Bhat (2011). Influence of girdling, thinning and GA3 on fruit quality and shelf life of grape (Vitis vinifera) cv. Perlette. Elixir Agriculture, 41: 5731-5735.

Raveh, E. (2013). Girdling for Crop Regulation. Citrus Growers Technical Conference and Workshop, Dareton.

Reginato, G.H. and K.G. Mesa (2011). Prohexadions-calcium and NAA sprays increase fruit weight of 'Castlebrite' apricot. Acta Hort., 903: 841-847.

Rivas, F., Y. Erner, E. Alos, M. Juan, V. Almela and M. Agusti (2006). Girdling increases carbohydrate availability and fruit set in citrus cultivars irrespective of parthenocarpic ability. Journal of Horticultural Science and Biotechnology, 81: 289-295. 
Rivas, F, A. Gravina and M. Agustí (2007). Girdling effects on fruit set and quantum yield efficiency of PSII in two citrus cultivars. Tree Physiology, 27: 527-535.

Rivas, F., F. Fernando and M. Agustí (2008). Girdling induces oxidative damage and triggers enzymatic and non-enzymatic antioxidative defenses in citrus leaves. Environ. Exp. Bot., 64: 256-263.

Roper, T.R. and L.E. Williams (1989). Net CO2 Assimilation and carbohydrate partitioning of grapevine leaves in response to trunk girdling and gibberellic acid application. Plant Physiol., 89: 11361140.

Roussos, P. and T. Anastassios (2011). Effects of girdling, nitrogen, zinc and auxin foliar spray applications on mandarin fruit "Nova" quality characteristics. J. Food Agric., 23(5): 431-440.

Said, I.A., F. M. Eissa and E.A. Kandil (2003). Effect of winter pruning, hand thinning, and girdling on 'Canino' apricot growth, yield, and quality. Minia J. Agric. Res. Dev., 23 (2): 301-328.

Saini, H.K., M.I.S. Gill and J.K. Sharma (2011). Effect of mechanical and chemical treatments on colour development of flame seedless grapes. Indian J. Ecol., 38: 91-93.

Sharma, G. and A.S. Ananda (2004). Effect of pre-bloom foliar application of plant bioregulators on growth, fruiting and quality of apple under warmer agroclimatic conditions. Acta Horticulturae, 662: 353-357.

Sharma, A.K., K. Singh and S.P. Mishra (2003). Effect of foliar spray on zinc sulphate, 2,4,5-T and GA3 on quality of Kagzi lime (Citrus aurantifolia Swingle). Orissa J. Hort., 31 (2): 29-32.

Singh, A.K., M.S. Mughal and A.M. Vachkoo (2002). Effect of ethrel and naphthalene acetic acid on fruit quality and fruit drop of 'Royal Delicious' apple. Indiant. Hort., 54 (4): 355-358.

Sousa, R.M., F. Calouro and C.M. Oliveira (2005). The effect of different rates of prohexadione-calcium and girdling on shoot growth and fruit quality when applied to different stores. Acta Hort., 564: 63-70.

Sousa, R.M., F. Calouro and C.M. Oliveira (2008). Influence of trunk girdling on growth and fruit production of 'Rocha'/BA29. Acta Hort., 800: 319-323.

Vemmos, S.N., A. Papagiannopoulou and S. Coward (2012). Effects of shoot girdling on photosynthetic capacity, leaf carbohydrate, and bud abscission in pistachio (Pistacia vera L.). Photosynthetica, 50 (1): 3548.

Verreynne, J.S., E. Rabe and K.I. Theron (2001). The effect of combined deficit irrigation and summer trunk girdling on the internal fruit quality of 'Marisol' Clementines. Sci. Hortic., 91:25-37. 
Wahdan, M.T., S.E. Habid, M.A. Bassal and E.M. Qaoud (2011). Effect of some chemicals on growth, fruiting, yield and fruit quality of 'Succary Abiad' mango cv. J. Amer. Sci., 7 (2): 651-658.

Wilde, S.A., R.B. Corey, J.G. Lyer and G.K. Voigt (1985). In: "Soil and Plant Analysis for Tree Culture". Published by Mohan Primlani, Oxford, IBH, Publishing Co., New Delhi, pp. 1-142.

Williams, L.E. and J.E. Ayars (2005). Water use of Thompson seedless grapevines as affected by the application of gibberellic acid (GA3) and trunk girdling practices to increase berry size. Agriculture and Forest Meteorology, 129: 85-94.

Wo, J., H.Z. Jia, K. Xu, Q.P. Wei and Z.L. Wei (2001). Effect of exogenous GA3 on the fruit development and endogenous hormones in "Fujiminori" grape. J. Fruit Sci., 18 (4): 209-212.

$\mathrm{Wu}$, J. and Lin, S. (2003). Effect of Naphthalene Acetic Acid on Fruit in 'Jiefanzhong' Loquat. In: "Llcer G. and M.L. Badenes (ed.)". First International Symposium on loquat Zaragoza: CIHEAM-IAMZ, pp. 109-112.

Yilmaz, B., B. Cimen, M. Incesu, T. Yesiloglu. M. Yilmaz (2018). Influence of girdling on the seasonal and leaf nutrition statues and fruit size of Robinson mandarin (Citrus reticulata). Applied Ecology and Environmental Research, 16 (5): 6205-6218.

Zhao, Y., L. Zhang, M. Gao, L. Tian, P. Zheng, K. Wang, L. Zhang, B. Li, M. Han, and A.K. Alva (2013). Influence of girdling and foliar applied urea on apple (Malus domestica L.) fruit quality. Pak. J. Bot., 45 (5): 1609-1615.

Egyptian J. Desert Res., 71, No. 1, 75-97 (2021) 


\title{
تأثير التحليق والجبرلين على المحصول وخصائص جودة ثمار اليوسفي \\ البلاي
}

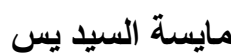 \\ قسم الإنتاج النباتي، مركز بحوث الصحر اء، المطرية، القاهرة، مصر
}

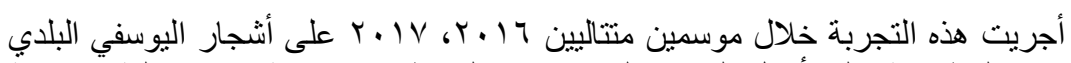

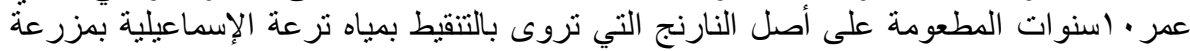

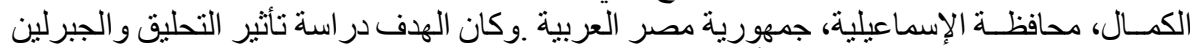

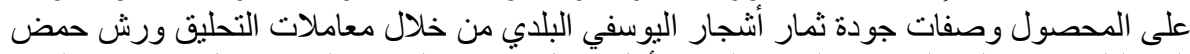

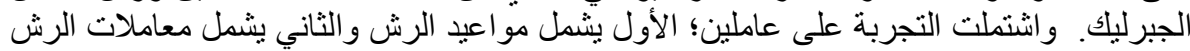

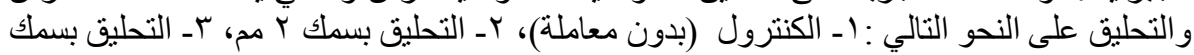

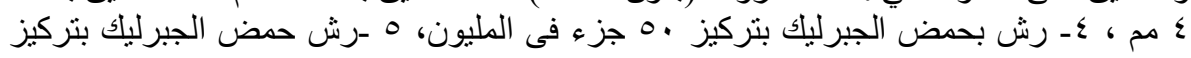

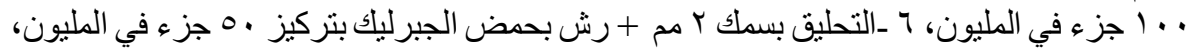

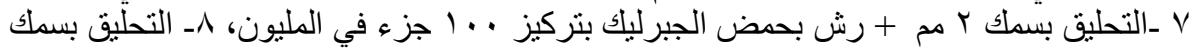

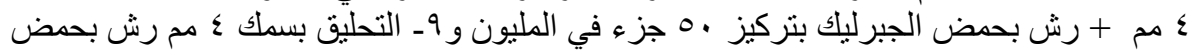

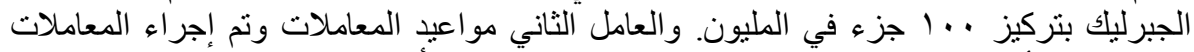

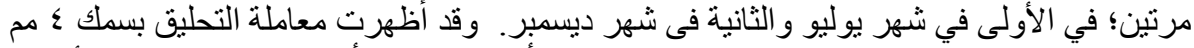

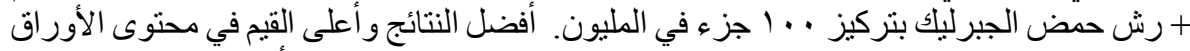

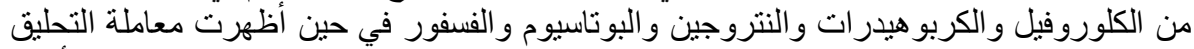

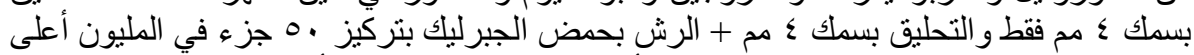

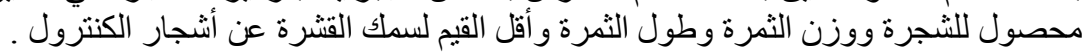

